\title{
Malignant Colorectal Neoplasm
}

National Cancer Institute

\section{Source}

National Cancer Institute. Malignant Colorectal Neoplasm. NCI Thesaurus. Code C4978.

A primary or metastatic malignant neoplasm that affects the colon or rectum.

Representative examples include carcinoma, lymphoma, and sarcoma. 